\title{
POR UM NOVO PARADIGMA JURÍDICO-DECISÓRIO NO QUE TANGE À RESOLUÇÃO DE CONFLITOS
}

\author{
NEW JURIDICAL DECISION-MAKING PARADIGM \\ CONCERNING CONFLICT RESOLUTION
}

\author{
JÂNIA MARIA LOPES SALDANHA ${ }^{1}$ \\ FERNANDO HOFFMAM ${ }^{2}$ \\ LARISSA NUNES CAVALHEIRO ${ }^{3}$
}

"Quando uma alma sensível e culta se lembra de seus esforços para desenhar, de acordo com o seu próprio destino intelectual, as grandes linhas da Razão, quando estuda, pela memória, a história de sua própria cultura, ela se dá conta de que, na base das certezas íntimas, fica sempre a lembrança de uma ignorância essencial".

Gaston Bachelard, A Intuição do Instante.

RESUMO: O presente texto tem por escopo investigar a necessidade da construção de um novo paradigma jurídico-decisório, no que tange à resolução de conflitos, pois, a partir do neoconstitucionalismo e da construção de um Estado

\footnotetext{
Artigo recebido em 31.08.2012. Pareceres emitidos em 19.10.2012 e 11.01.2013.

Artigo aceito para publicação em 10.03.2013.

${ }^{1}$ Doutora em Direito Público pela Universidade do Vale do Rio dos Sinos (UNISINOS - RS), Professora do Programa de Pós-Graduação - Mestrado - e da Graduação em Direito da Universidade Federal de Santa Maria (UFSM - RS). Advogada. janiasaldanha@gmail.com

${ }^{2}$ Mestrando em Direito Público pela Universidade do Vale do Rio dos Sinos (UNISINOS - RS), Bolsista PROSUP/CAPES, Membro dos Grupos de Pesquisa Teoria Crítica do Processo e Delmas-Marty: Internacionalização do Direito e Emergência de Um Direito Mundial, vinculados à UNISINOS - RS e ao CNPQ, Especialista em Direito: Temas Emergentes Em Novas Tecnologias Informacionais pelo Centro Universitário Franciscano (UNIFRA - RS), Membro do Grupo de Pesquisa Teoria Jurídica no Novo MiLenio, vinculado à UNIFRA e ao CNPQ, Bacharel em Direito pelo Centro Universitário Franciscano (UNIFRA - RS). ferdhoffa@yahoo.com.br

${ }^{3}$ Mestranda em Direitos Emergentes na Sociedade Global pela Universidade Federal de Santa Maria (UFSM - RS), Especialista em Direito Público pela Escola Superior da Magistratura Federal (ESMAFE - RS); Especialista em Educação Ambiental pela Universidade Federal de Santa Maria (UFSM - RS); Integrante do grupo de pesquisa "Ativismo digital e as novas mídias: desafios e oportunidades da cidadania global", vinculado a UFSM - RS, aluna especial do Mestrado em Filosofia e Graduanda em Filosofia na mesma instituição; Bacharel em Direito pelo Centro Universitário Franciscano (UNIFRA - RS). Advogada. laranunes7@hotmail.com
} 
Democrático de Direito em terrae brasilis, após a Constituição de 1988, surgiram novos direitos, fecundando novos conflitos no âmago da sociedade. Dessa forma, não é possível pensar a decisão jurídica como algo que simplesmente põe fim ao conflito. A decisão jurídica que se deve ao novo paradigma é aquela que, a partir de um agir - em processo - hermenêutico-integrativo e, calcada em um processo-jurisdição democrático-constitucionalizado, abarque a complexidade da sociedade contemporânea e, ao desvelar-se no momento decisório, tenha o condão de garantir e concretizar os direitos albergados constitucionalmente.

PALAVRAS-CHAVE: Processo; Jurisdição; Decisão Jurídica; Hermenêutica; Integridade.

ABSTRACT: This text aims to investigate the need of creating a new juridical decision-making paradigm concerning conflict resolution, since new laws appeared from neo-constitutionalism and the building of a Democratic Rule of Law through the 1988 Constitution in Brazil which created new conflicts in society. Thus, it is not possible to think of juridical decision as something that stops conflict. The juridical decision suitable to the new paradigm is that which from a hermeneutic integrative action in process and based on a democratic and constitutionalized process-jurisdiction embraces the complexity of contemporary society, and by revealing itself during the decision-making process guarantees and realizes the laws constitutionally sheltered.

KEYWORDS: Process; Jurisdiction; Juridical Decision; Hermeneutics; Integrity.

SUMÁRIO: Introdução; 1. Considerações sobre o Processo Jurisdicional: Da modernidade á pós-modernidade; 2. A Transformação das Demandas na Contemporaneidade e a Necessidade de uma Decisão Jurídica que Supere a Mera Resolução do Conflito; Considerações Finais; Referências.

SUMMARY: Introduction; 1. A Few Considerations on Processual Jurisdiction: From modernity to post-modernity; 2 . The Transformations in Judicial Demands in Contemporary Times and Necessity of a Theory of Judicial Decision that does not Simply Solves Conflicts; Conclusions; References.

\section{INTRODUÇÃO}

$\mathrm{Na}$ modernidade, o Direito viu-se limitado pelas construções teóricas do liberalismo que eclodiram na Europa após a revolução burguesa. A partir daí, constroi-se um modelo de Estado estruturado sobre uma lógica individualprivatista, preocupado somente em proteger os sujeitos jurídicos dos abusos promovidos por ele próprio - Estado. É marca desse tempo um modelo estatal mínimo, que visa apenas proteger as liberdades individuais e, sobremodo, a propriedade privada e o contrato, assim como a economia de mercado. Assim, os conflitos produzidos nesse momento envolvem meramente direitos individuais e, dessa forma, exigem uma solução simpl(ista)es, que somente ponha fim ao conflito.

No entanto, ao passar do modelo liberal à roupagem social de Estado, passa-se a exigir do Estado um pouco mais do que no antigo regime. O Estado Social surge com a intenção de trazer o adjetivo social para o seio da sociedade, instaurando, assim, a questão social no Direito. Neste caminho, - Estado deixa de ser meramente não interventor e passa a ser um possibilitador da questão social no âmago da comunidade. Ao lado dos direitos 
e prestações negativas do modelo Liberal, adentram a esfera político-jurídica, direitos e prestações positivas, fazendo com que o Direito - e nesta tendência o processo-jurisdição - passem a ser possibilitadores da questão social, ocasionando um novo agir do Estado e da jurisdição.

Nesta senda, a eclosão do neoconstitucionalismo e a instituição do Estado Democrático de Direito, acarretam uma complexificação ainda maior do viver em sociedade e, para além dos modelos mantenedor - Estado Liberal - e promovedor - Estado Social - de Estado, constitui um modelo modificador das condições sociais. A instituição do Estado Democrático de Direito significa um plus normativo no que tange aos modelos anteriores, trazendo em seu bojo como marca indelével a preocupação com uma substancialidade constitucional. Ademais, nas constituições do pós-guerra afloram uma série de direitos não existentes anteriormente, que mais do que positivados constitucionalmente, devem ser garantidos e concretizados em sua materialidade.

Tais modificações, como o surgimento de novos direitos - transindividuais, individuais homogêneos, difusos, coletivos -, geram uma complexificação, bem como um aumento significativo da conflituosidade. Assim, os conflitos que antes exigiam uma resposta simplista - simples - meramente normativa, passam a exigir um agir positivo da jurisdição, além do que, uma resposta que, para além de por fim ao conflito, seja capaz de garantir e concretizar direitos.

Desta forma, será traçado um panorama dos modelos de Estado e jurisdição da modernidade à pós-modernidade, buscando-se realçar os contornos da conflituosidade moderna e das respostas que por essa conflituosidade eram exigidas, bem como, de como o processo-jurisdicional se coloca na pós-modernidade (Parte 1). Passado esse momento, buscar-se-á compreender o surgimento de um novo paradigma estatal e, com ele, a necessária construção de um novo paradigma processo-jurisdicionaldecisório e a possibilidade de, a partir de uma teoria hermenêutico-integrativa da decisão, construir-se um novo paradigma jurídico-decisório no que tange à resolução de conflitos (Parte 2).

\section{CONSIDERAÇÕES SOBRE O PROCESSO JURISDICIONAL: DA MODERNIDADE À PÓS-MODERNIDADE}

A ciência jurídica atualmente, se encontra desafiada a superar velhos paradigmas, propondo soluções aos institutos tradicionais. O direito processual civil é um dos ramos do Direito que se percebe profundamente tocado por esse desafio, uma vez que está enraizado em um paradigma de matizes e matrizes moderno-racionalistas, instituídas pelo Estado Liberal. Este serviu de pilar-base para a jurisdição liberal, alicerçada em uma dogmática normativopositivista acrítica, que não admite a interpretação da lei (norma), mas somente a sua aplicação na busca por verdades absolutas. ${ }^{4} \mathrm{O}$ Direito da modernidade,

\footnotetext{
${ }^{4}$ LUCAS, Doglas Cesar. A Crise Funcional do Estado e o Cenário da Jurisdição Desafiada. In: BOLZAN DE MORAIS, José Luis (Org). O Estado e Suas Crises. Porto Alegre: Livraria do Advogado, 2005, p. 169-224.
} 
portanto, é apresentado como um projeto sistematizado de exatidão e confiabilidade, atendendo a uma "calculabilidade", possuindo a pretensão de livrar o tráfego de mercadorias de possibilidades de incertezas. ${ }^{5}$

No Estado Liberal, o Direito - e mais ainda a jurisdição liberal preocupava-se com os direitos do indivíduo, ou seja, em resolver conflitos individuais de direitos, bem como em manter e consolidar o estado de liberalismo econômico. Era dever do judiciário a defesa da propriedade privada, da liberdade contratual, da garantia do livre comércio e do desenvolvimento industrial, pilares vitais para ascensão e para a consolidação burguesa. ${ }^{6}$

Neste trilhar, mostra-se o liberalismo como uma concepção estatal balizada pelas pretensões oriundas do homem enquanto ser individualizado, já que o aspecto central de suas determinações era o indivíduo, devendo a atividade estatal preocupar-se com um espectro mínimo da vida político-social. Suas tarefas, frente aos sujeitos sociais, eram tão somente garantir-lhes ordem e segurança, salvaguardando, assim, as liberdades civis e a liberdade pessoal, bem como, assegurando-Ihes da mesma forma a economia, que deveria ser consolidada no âmbito do livre mercado. ${ }^{7}$

Entretanto, para que seja possível falar do sistema processual moderno, há também que se trabalhar a concepção positivista do direito enquanto sistema normativo fechado. Para esta visão positivista, seria o Direito nascido dele próprio, tendo sua validade determinada pela norma fundamental de Kelsen ${ }^{8}$ - sendo concebido, o Direito, como um sistema de normas que decorrem desta norma fundamental pressuposta - em Hart a norma de conhecimento e em Ross a norma básica - não guardando espaço para quaisquer fenômenos que não sejam jurídicos ${ }^{9}$. Logo, fica evidente que "a teoria positivista pretende apenas ser método, lógica, sistema, assim manter-se, respeitosamente, distante das valorações, dos efeitos míticos e políticos de sua própria prática social. Assim a ciência jurídica imuniza-se

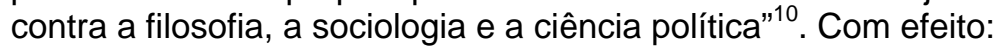

Na modernidade, a fé no progresso foi acompanhada pela fé na razão, que seria o instrumento apropriado para o conhecimento certo da realidade. Valendo-se da razão o homem poderia aperfeiçoar-se como "artífice de

\footnotetext{
${ }^{5}$ HOMMERDING, Adalberto Narciso. Fundamentos para uma Compreensão Hermenêutica do Processo Civil. Porto Alegre: Livraria do Advogado, 2007, p. 45.

${ }^{6}$ BOLZAN DE MORAIS, José Luis; STRECK, Lenio Luiz. Ciência Política e Teoria do Estado. Porto Alegre: Livraria do Advogado, 2010. Passim.

7 BOLZAN DE MORAIS, José Luis; STRECK, Lenio Luiz. Ciência Política e Teoria do Estado. Porto Alegre: Livraria do Advogado, 2010, p. 61.

${ }^{8}$ BARZOTTO, Luis Fernando. O Positivismo Jurídico Contemporâneo: uma introdução a Kelsen, Ross e Hart. Porto Alegre: Livraria do Advogado, 2007. Passim.

${ }^{9}$ KELSEN, Hans. Teoria Pura do Direito. Tradução: João Baptista Machado. São Paulo: Martins Fontes, 2006, p. 79-85.

${ }^{10}$ WARAT, Luis Alberto. Introdução Geral ao Direito II: a epistemologia jurídica da modernidade. Porto Alegre: Sergio Antonio Fabris, 1995, p. 104.
} 
seu próprio destino". Poderia conquistar sua autonomia. No âmbito jurídico da modernidade, pois, o progresso consistiu em deixar de lado os costumes e leis que tinha por base o acontecer histórico das diversas sociedades, para elaborar um direito que tinha base em critérios estritamente racionais: o direito produzido pelo espírito da ilustração deveria atender unicamente às leis próprias da razão, pela qual se poderiam alcançar princípios fixos e imutáveis, cuja validade não estivesse sujeita às contingências espaçotemporais próprias do acontecer histórico. ${ }^{11}$

Ainda no que tange ao Estado Liberal, insta salientar que os detentores do poder, ou seja, a burguesia revolucionária, estavam preocupados em manter o que haviam conquistado a partir das revoluções burguesas. Nesse ambiente, a jurisdição não podia ser percebida enquanto tarefa interpretativa, haja vista a formação da magistratura no âmago da aristocracia. É assim que se engessaria a atividade da jurisdição-processual, que acabou sendo tratada como uma mera atividade reveladora das vontades - verdades - da lei.

Isso explica porque a teoria da jurisdição - processual - moderna está assentada na busca por "verdades" que se materializam ao final do iter processual - em regra, ordinário. Tais "verdades" ganham o selo da certeza e da eternidade histórica por estarem baseadas na norma posta e serem a verdade do soberano - poder jurídico-político constituído -, que deverá ser proclamada pelo juiz ao final do processo ${ }^{12}$. Daí forjou-se uma atividade jurisdicional pronta a jurisdicionalizar apenas o que está posto pelo Estado, a fim de ultimar segurança jurídica, elemento vital para o desenvolvimento do liberal-individualismo. ${ }^{13}$

Assim, funda-se um modelo de tutela jurisdicional baseado no conflito entre particulares ou entre particulares e o Estado - apenas quando o ente estatal adentra uma área de convívio que não é a sua -, de modo a resolver tais conflitos aplicando a norma posta. Por tal, o conflito nada mais é do que uma disputa monetário-individual, após originar-se o dano, não havendo mais nada a fazer do que quantificá-lo monetariamente.

A jurisdição moderna atinha-se às individualidades dos sujeitos de direito, procurando solução para os conflitos individuais oriundos da ordem sócio-econômica liberal, não estando o Sistema de Justiça preparado para resolver os conflitos transindividuais da pós-modernidade. Ademais, forja-se a ordem jurídica liberal sob as bases do paradigma moderno-racionalista, sendo a jurisdição afastada da vida em sociedade geradora de tantas angústias aos sujeitos jurídico-sociais. O Direito moderno está livre de toda e qualquer

\footnotetext{
${ }^{11}$ HOMMERDING, Adalberto Narciso. Fundamentos para uma Compreensão Hermenêutica do Processo Civil. Porto Alegre: Livraria do Advogado, 2007, p. 43.

${ }^{12}$ SILVA, Ovídio A. Baptista da. Processo e Ideologia: o paradigma racionalista. Rio de Janeiro: Forense, 2006. Passim.

${ }^{13}$ HOMMERDING, Adalberto Narciso. Fundamentos para uma Compreensão Hermenêutica do Processo Civil. Porto Alegre: Livraria do Advogado, 2007, p. 91.
} 
insegurança e incerteza, pois a norma posta pelo legislador não deixa margem a faltas ou lacunas legislativas, estando previsto normativamente todo e qualquer conflito. ${ }^{14}$ Com efeito:

[...] o judiciário foi estruturado para operar por meio de uma lógica racional-legal que nega a complexidade, que valoriza exageradamente as formalidades e os procedimentos decisórios de tempo diferido e que mascara a substancialidade dos conflitos sociais e econômicos pela adoção de fórmulas e conceitos reducionistas afinados com uma cultura de conservação do projeto liberal-individualista. ${ }^{15}$

Veja-se que a conflituosidade moderna vem marcada também pelas características principais do liberalismo: o individualismo, a hipostasiação da norma, do contrato, da propriedade privada, a garantia do "mercado" e, sobremodo, a racionalização dos conflitos em um mero caráter ressarcitório. Não há que se pensar, aqui, em garantia de qualquer direito que não o de contratar e ter propriedade. ${ }^{16}$

No entanto, tal situação modifica-se quando se passa do Estado Liberal ao Estado Social, o que culmina na busca por uma maior sociabilidade do acontecer jurídico-político. A modalidade estatal social vem marcada por uma primeira ruptura com o modelo Liberal e, sobremodo, pelo incremento das funções do Estado, que passa de um modelo meramente protetor e ingerente, a um modelo que deve gerenciar a questão social.

Nesse sentido, agrega-se ao Direito um conteúdo social em que, nesta nova roupagem estatal, são recebidos os valores jurídico-políticos do modelo liberal, dando-se a estes um novo significado condizente com o presente social. Assim, além de forjados certos direitos para limitar a atividade do Estado, são concedidos aos sujeitos jurídico-sociais direitos a prestações estatais. Logo, a partir do advento do Estado Social de Direito, "projeta-se um modelo onde o bem-estar e o desenvolvimento social pautam as ações do ente público". ${ }^{17}$

Aqui transita o Direito Processual de um processualismo liberal determinado pelos direitos individuais das partes e, eminentemente escrito, a um processualismo social(izado) que, a partir da oralidade, funda o juiz como um persecutor ativista dos anseios sociais. ${ }^{18}$ Instaura-se, assim, uma forma de

\footnotetext{
${ }^{14}$ HOMMERDING, Adalberto Narciso. Fundamentos para uma Compreensão Hermenêutica do Processo Civil. Porto Alegre: Livraria do Advogado, 2007. Passim.

${ }^{15}$ LUCAS, Doglas Cesar. A Crise Funcional do Estado e o Cenário da Jurisdição Desafiada. In: BOLZAN DE MORAIS, José Luis (Org). O Estado e Suas Crises. Porto Alegre: Livraria do Advogado, 2005, p. 169-224.

${ }^{16}$ LUCAS, Doglas Cesar. A Crise Funcional do Estado e o Cenário da Jurisdição Desafiada. In: BOLZAN DE MORAIS, José Luis (Org). O Estado e Suas Crises. Porto Alegre: Livraria do Advogado, 2005, p. 169-224.

${ }^{17}$ BOLZAN DE MORAIS, José Luis; STRECK, Lenio Luiz. Ciência Política e Teoria do Estado. Porto Alegre: Livraria do Advogado, 2010, p. 96.

${ }^{18}$ NUNES, Dierle José Coelho Nunes. Apontamentos Iniciais de um Processualismo Constitucional Democrático. In: OLIVEIRA, Marcelo Andrade Cattoni de; MACHADO, Felipe Daniel Amorim (Org).
} 
tutela jurisdicional interventivo-ativista, que surge com a função de qualificar socialmente o modelo de Estado. Este novo modelo tem por norte a busca da implementação da questão social nos espaços político-jurídicos, que antes estavam apartados de tais discussões. ${ }^{19}$

Nesse caminho, o juiz torna-se verdadeiro intérprete do Direito, cabendo-Ihe a missão de, ao interpretar os textos legislativos ou suprir as lacunas deixadas pelo mesmo - texto -, tornar possível a questão social. Deste modo, discricionariamente, o juiz ora declarador de vontades, torna-se um juiz construtor do arcabouço político-social, que só vai ser totalmente construído a partir da atividade jurisdicional marcadamente intensa nestes novos tempos. ${ }^{20}$

Passado esse momento, chega-se ao paradigma jurídico-estatal pósmoderno, qual seja o paradigma do Estado Democrático de Direito, que não pode ser dissociado do novo constitucionalismo, nem tampouco pode ser tratado como uma mera passagem de modelo. Ademais, é nesse ponto da história que a teoria jurídico-estatal ganha um caráter transformador das circunstâncias político-sociais, perpassando, dessa maneira, o feitio mantenedor do status quo - característica do Estado Liberal -, bem como o de mero adaptador das condições sociais a um melhoramento superficial - Estado Social. ${ }^{21}$

A noção de Estado Democrático de Direito está, pois, indissociavelmente ligado à realização dos direitos fundamentais. É desse liame indissolúvel que exsurge aquilo que se pode denominar de plus normativo do Estado Democrático de Direito [...]. A essa noção de Estado se acopla o conteúdo das Constituições, através dos valores substantivos que apontam para uma mudança no status quo da sociedade. Por isso, como já referido anteriormente, no Estado Democrático de Direito a lei (Constituição) passa a ser uma forma privilegiada de instrumentalizar a ação do Estado na busca do desiderato apontado pelo texto constitucional, entendido no seu todo dirigente-valorativo-principiológico. ${ }^{22}$

\footnotetext{
Constituição e Processo: a contribuição do processo ao constitucionalismo democrático brasileiro, Belo Horizonte: Del Rey, 2009, p. 349-362.

${ }^{19}$ ISAIA, Cristiano Becker. Processo Civil, Atuação Judicial e Hermenêutica Filosófica: a metáfora do juiz instrutor e a busca por respostas corretas em direito. Faticidade e Oralidade. Curitiba: Juruá, 2010, p. 40.

${ }^{20}$ CAPPELLETTI, Mauro. Juízes Legisladores?. Tradução: Carlos Alberto Alvaro de Oliveira. Porto Alegre: SAFE, 1999, p. 21-22. Embora não seja escopo do presente trabalho, insta referir que há que se tomar muito cuidado com a passagem do modelo processual liberal ao social. Porquanto não seja compatível com o paradigma do Estado Democrático de Direito um procesualismo inerte, calcado na resolução de conflitos meramente de cunho individualpatrimonialista, a partir, da não menos mera subsunção fato-norma. Também não se coaduna com o novo paradigma, um processualismo que erige à condição de oráculo da questão social a figura do juiz, passando esse a ser um interventor ativista sem limites, na persecução do implemento do social (STRECK, Lenio Luiz. O Que é Isto - decido conforme a minha consciência?. Porto Alegre: Livraria do Advogado, 2010. Passim).

${ }^{21}$ BOLZAN DE MORAIS, José Luis; STRECK, Lenio Luiz. Ciência Política e Teoria do Estado. Porto Alegre: Livraria do Advogado, 2010, p. 97.

${ }^{22}$ STRECK, Lenio Luiz. Hermenêutica Jurídica $e(m)$ Crise: uma exploração hermenêutica da construção do Direito. Porto Alegre: Livraria do Advogado, 2005, p. 40.
} 
Desse modo, é evidente que o modelo jurisdicional moderno sofre uma ruptura na pós-modernidade, atravessando uma crise de gigantescas proporções, pois: (a) não consegue resolver os conflitos transindividuais inerentes à modernidade líquida, para lembrar Bauman; (b) não consegue dar vazão ao imenso número de processos que chegam às portas do judiciário; (c) não consegue concretizar os direitos garantidos constitucionalmente, e, sendo assim; (d) não é capaz de amortizar o caos social em que se encontra o mundo moderno - aqui com o sentido de contemporâneo.

No entanto, essa ruptura se dá de maneira apenas aparente, visto que o processo jurisdicional em si segue aferrado aos grilhões dos paradigmas da modernidade - individualismo, capitalismo, liberalismo - e, agora, os potencializa - hiperindividualismo, mercado global, neoliberalismo.

O processo jurisdicional não mais é moderno, agora ele é hipermoderno, calcado na lógica do mercado não dá suporte aos sujeitos jurídico-sociais na resolução - substancial - dos conflitos. Obedece uma lógica de resolução aparente, rápida, à custo baixo e segura, preocupada em manter o pleno funcionamento do mercado. O modelo de processo cunhado na pósmodernidade - hipermoderna ${ }^{23}$ - segue a resolver tão somente os conflitos jurídicos da modernidade.

Delimita-se assim a tão falada crise da jurisdição e, porque não, do processo como um todo, que é, também, expressão da crise do Estado que

\footnotetext{
${ }^{23}$ Se faz necessário nesse momento que se faça alguns esclarecimentos sobre o termo pós-modernidade, bem como, sobre a condição do homem nesse dado momento. Lyotard compreende a pós-modernidade como uma época marcada pelo fim das grandes narrativas, ou seja, uma época de reordenação dos saberes, o que provoca um esfacelamento das instituições modernas, como, os Estados-nação que, não mais detém o "monopólio" do saber, o controle sobre os caminhos e descaminhos do político-social (LYOTARD, Jean-François. A Condição Pós-Moderna. Tradução: Ricardo Corrêa Barbosa. Rio de Janeiro: José Olympio, 2011, p. 3-7). Lipovetsky, no entanto, encara a pós-modernidade como um momento de transição, para o autor, a designação pós-modernidade tinha o mérito de indicar uma mudança de rumos nos caminhos da modernidade, a partir da rápida expansão do consumo e da comunicação de massa, exacerbação do individualismo, consagração do hedonismo, etc. No entanto, tratava-se também de uma expressão ambígua, porque não designava um período de mera superação da modernidade, mas sim de continuação daquela anterior. "No momento em que triunfam a tecnologia genética, a globalização liberal e os direitos humanos, o rotulo pós-moderno já ganhou rugas, tendo esgotado sua capacidade de exprimir o mundo que se anuncia". Devido a esse esgotamento do termo pós-modernidade, a partir da potencialização de algumas características da modernidade, consubstancia-se a terminologia hipermodernidade, para designar uma época de hipercapitalismo, hiperclasse, hiperterrorismo, hiperindividualismo, etc. (LIPOVETSKY, Gilles; CHARLES, Sebastien. Os Tempos Hipermodernos. Tradução: Mário Vilela. São Paulo: Barcarolla, 2004, p. 52-53). Desse modo, a utilização do termo "pós-modernidade hipermoderna" liga-se ao modo como Chevallier - ao falar do Estado - vê o momento atual. O autor trabalha a pósmodernidade num jogo, hipermoderno-antimoderno, onde, ao se falar em hipermodernidade, falase em uma dimensão histórico-social que eleva ao máximo certas características da modernidade como o individualismo, ao passo que, ao se falar em antimodernidade se delineia uma categoria - mundana - que se desvincula de alguns dos postulados modernos (CHEVALLIER, Jacques. O Estado Pós-Moderno. Tradução: Marçal Justen Filho. Belo Horizonte: Fórum, 2009, p. 20).
} 
avança disfuncionalizado ao Estado Democrático de Direito, provocando uma crise funcional e estrutural no que tange ao Direito e, mais especificamente, ao processo. Ainda, o surgimento de uma nova conflituosidade oriunda de novos direitos - coletivos, individuais homogêneos, difusos -, bem como a atribuição de capacidade atuante a novos atores jurídico-sociais, intensifica tal processo. Tais circunstâncias geram um déficit da jurisdicionalidade que não suporta a crescente litigiosidade. ${ }^{24}$

No Estado Democrático de Direito intensifica-se a chamada à jurisdição, a partir da positivação de novos direitos e a atividade jurisdicional passa a ter um caráter construtivo do jurídico. O Direito, em meio ao novo paradigma, passa a ser demarcado pelo texto constitucional, o que provoca uma alteração conteudística da decisão jurídica, passando essa - decisão jurídica - a operar em uma esfera de garantia e concretização dos Direitos humano-fundamentaissociais, o que desnuda, seguramente, um déficit de modelo decisório.

\section{A TRANSFORMAÇÃO DAS DEMANDAS NA CONTEMPORANEIDADE E A NECESSIDADE DE UMA DECISÃO JURÍDICA QUE SUPERE A MERA RESOLUÇÃO DO CONFLITO}

Neste plano, adentra-se ao paradigma do Estado Democrático de Direito buscando um novo padrão jurídico-decisóriono concernente à função jurisdicional, isto porque o Direito está jogado à complexidade da sociedade de risco, às relações jurídicas transindividuais, à explosão de uma conflituosidade baseada em novos direitos e, por tal, deve adequar-se a um novo panorama político-social desafiador não só da tutela jurisdicional, como também, da decisão jurídica em si.

Este novo paradigma estatal vem em compasso com a construção neoconstitucionalista representada pela inserção de princípios nos textos constitucionais, como também pela ampliação do espectro de atuação da Carta Constitucional. As constituições do segundo pós-guerra surgem adjetivadas de compromissárias e dirigentes, bem como, invasoras do espaço público administrativo. Tal invasão, quando fomentada por parte do Judiciário, não pode ser compreendida em uma lógica que possibilite ativismos por parte do Estado-juiz em que o intérprete sob o manto - rasgado - da Constituição do seu concretizar - venha a agir de maneira arbitrária e solipsista na busca pela realização da Constituição que, em verdade, dessa forma, estará sendo vilipendiada ${ }^{25}$.

Neste trilhar, a Constituição brasileira de 1988 adentra o signo do dirigismo constitucional compromissada com os anseios de uma sociedade abandonada em suas necessidades, não ficando apenas limitada à definição de questões

\footnotetext{
${ }^{24}$ SPENGLER, Fabiana Marion. A Crise da Jurisdição e a Necessidade de Superação da Cultura Jurídica Atual: uma análise necessária. In: BRANDÃO, Paulo de Tarso; SPENGLER, Fabiana Marion (Org). Os (Des)Caminhos da Jurisdição. Florianópolis: Conceito, 2009, p. 64-94.

${ }^{25}$ STRECK, Lenio Luiz. O Que é Isto - decido conforme a minha consciência?. Porto Alegre: Livraria do Advogado, 2010, p. 102-107.
} 
meramente político-administrativas. Invade também as esferas econômica e social, pois preocupada em concretizar e garantir os direitos emanados dela mesma - Constituição. Desta maneira, constitui-se não só uma nova Constituição, como também um novo Direito capaz de garantir a substancialidade constitucional. Assim:

[...] de um direito meramente reprodutor da realidade, passa-se a um direito com potencialidades de transformar a sociedade, como, aliás, consta no texto da Constituição do Brasil. O direito, nos quadros do Estado Democrático (e Social) de Direito, é sempre um instrumento de transformação, porque regula a intervenção do Estado na economia, estabelece a obrigação da realização de políticas públicas, além do imenso catálogo de direitos fundamentais-sociais. ${ }^{26}$

E é neste caminho em que se constroi um novo Direito, que se deve também construir um novo processo. Exige-se, nessa perspectiva, um Direito Processual democrático-constitucional(izado); um processo que tenha por norte a efetivação do texto constitucional, que possibilite a participação cidadã no acontecer da democracia, dando voz aos sujeitos jurídico-sociais e implementando os direitos garantidos constitucionalmente. ${ }^{27}$

Nessa perspectiva de constitucionalizar-se o processo, faz-se necessário fundar uma "jurisdição constitucional(izada)"28. Jurisdição esta que, levando em conta a materialidade constitucional, refunde o direito no passo do novo paradigma, instituindo um modo-de-ser processual democrático e constitucional. Capaz de dar vida ao texto da Constituição garantindo e concretizando os direitos humano-fundamentais-sociais que a Carta Política alberga.

Desse modo, busca-se para o centro da discussão jurídico-processual a preocupação com a substancialidade constitucional, perfectibilizada no acontecer dos conteúdos referentes aos direitos humanos, sobremodo, atinentes aos interesses coletivos. Logo, exige-se um(a) processo/jurisdição

\footnotetext{
${ }^{26}$ STRECK, Lenio Luiz. Verdade e Consenso: constituição, hermenêutica e teorias discursivas. Rio de Janeiro: Lumen Juris, 2006, p. 2.

27 NUNES, Dierle José Coelho. Apontamentos Iniciais de um Processualismo Constitucional Democrático. In: OLIVEIRA, Marcelo Andrade Cattoni de; MACHADO, Felipe Daniel Amorim (Org). Constituição e Processo: a contribuição do processo ao constitucionalismo democrático brasileiro, Belo Horizonte: Del Rey, 2009, p. 349-362.

${ }^{28}$ A partir deste momento, usar-se-á o termo "jurisdição constitucionalizada" em detrimento do termo "jurisdição constitucional". Tal opção, dá-se pela possibilidade de se entender o termo "jurisdição constitucional" como um modelo jurisdicional face a uma jurisdição não-constitucional, estando-se assim aprisionados a uma concepção metafísico-dualista. Já, ao empregar-se o termo "jurisdição constitucionalizada" tem-se o sentimento de que todo o espaço jurisdicional foi constitucionalizado, ou seja, que a Constituição passou a habitar as entranhas do sistema jurídico e, assim, também, do Direito Processual, não cabendo em meio ao novo paradigma operar-se sob uma concepção dualista que cindi a atividade jurisdicional em constitucional e ordinária (HOMMERDING, Adalberto Narciso. Fundamentos para uma Compreensão Hermenêutica do Processo Civil. Porto Alegre: Livraria do Advogado, 2007. Passim).
} 
constitucionalizados, assentados nos princípios político-constitucionais e aptos a congregar em si a conteudística referente a uma nova prática social. ${ }^{29}$

Neste sentido, a já falada crise do processo e da jurisdição toma corpo devido ao descompasso entre um processo - jurisdição - que ainda não assumiu os conteúdos democrático-constitucionais que lhe foram apresentados e uma estrutura social que, ao não ver concretizados materialmente os seus direitos e garantias fundamentais, foi buscar na jurisdição o meio apto para concretizá-los. Fica claro que as novas categorias de direitos, surgidas no bojo do Estado Social e do Estado Democrático de Direito, produziram demandas altamente complexificadas pelo novo arranjo social. ${ }^{30}$

A atividade jurisdicional nesse novo contexto histórico deve assumir para si a condição de possibilitadora do aflorar de um verdadeiro Estado Democrático de Direito. Abandonando o modelo de decisão imobilizadora do conflito, que no antigo sistema - positivo-racionalista - tem um caráter liberalindividualista e, assumindo para além da mera solução da controvérsia, a realização democrático-constitucional do direito materialmente compreendido. ${ }^{31}$

O que importa à jurisdição enquanto efetividade e eficácia é o oferecimento ao cidadão de meios aptos a realizar o direito material - os direitos materialmente albergados no texto constitucional. Se o processo contemporâneo permanecer ligado aos institutos tutelares imóveis da processualística moderna e não se preocupar em alcançar aos sujeitos

\footnotetext{
${ }^{29}$ BOLZAN DE MORAIS, José Luis; SALDANHA, Jânia Maria Lopes; ESPíNDOLA, Ângela Araújo da Silveira. Jurisdição Constitucional e Participação Cidadã: por um processo formal e substancialmente vinculado aos princípios político-constitucionais. In: OLIVEIRA, Marcelo Andrade Cattoni de; MACHADO, Felipe Daniel Amorim. (Org). Constituição e Processo: A colaboração do processo ao constitucionalismo democrático brasileiro. Belo Horizonte: Del Rey, 2009, p. 113-141.

${ }^{30}$ SPENGLER, Fabiana Marion. A Crise da Jurisdição e a Necessidade de Superação da Cultura Jurídica Atual: uma análise necessária. In: BRANDÃO, Paulo de Tarso; SPENGLER, Fabiana Marion (Org). Os (Des)Caminhos da Jurisdição. Florianópolis: Conceito, 2009, p. 64-94.

${ }^{31}$ SALDANHA, Jânia Maria Lopes Saldanha. A Jurisdição Partida ao Meio: a (in)visível tensão entre eficiência e efetividade. In: STRECK, Lenio Luiz; BOLZAN DE MORAIS, José Luis (Org). Constituição, Sistemas Sociais e Hermenêutica: anuário do programa de pós-graduação em Direito da UNISINOS - $n^{\circ}$ 6. Porto Alegre: Livraria do Advogado, 2010, p. 75-100. Cabe referir aqui, que esta mudança na lógica jurisdicional da modernidade - busca pela mera resolução do conflito -, para a contemporaneidade - busca pela concretização dos direitos e garantias albergados no texto constitucional -,está inserida na mudança da lógica estatal - Estado Liberal, para o Estado Social e para o Estado Democrático de Direito - como trabalhada por Mirjan Damaska. O referido autor compreende esta passagem do Estado Liberal ao Estado Democrático de Direito inserida na passagem de um Estado de perfil reativo, para um modelo estatal de perfil ativo. A construção paradigmático-estatal de perfil reativo - Estado Liberal - contenta-se com uma função jurisdicional que meramente ponha fim ao conflito, enquanto, o paradigma instituído pelo Estado Democrático de Direito - também se estende tal compreensão ao Estado Social guarda relação com um perfil ativo de Estado, onde, para além da resolução do conflito, a partir desse, concretiza-se e/ou garante-se direitos de cunho fundamental-social. Ver: (DAMASKA, Mirjan. R. Las Caras de la Justicia y el Poder del Estado: análisis comparado del processo legal. Tradução: Andrea Morales Vidal. Santiago: Editorial Jurídica de Chile, 2000).
} 
jurídico-sociais meios de efetivar o direito material que lhes foi usurpado, estará distante abismalmente da atividade jurisdicional compatível ao Estado Democrático de Direito ${ }^{32}$. Com efeito:

[...] o processo judicial, se na sua origem, significava deslindar e interromper a incerteza, consistindo na fase terminal de um drama, amiúde individual, com vários personagens, muda de horizonte. Destina-se a promover a concretização dos valores constitucionais. Da finalidade de curto prazo - então a solução do caso individual - passa-se à finalidade de longo prazo - consolidação dos valores democráticos e a paz pública. ${ }^{33}$

Logo, nesse caminhar, se mostra necessário também a construção de um novo modelo de decisão jurídica, alinhada com o novo paradigma. Decisão que, em tempos neo-constitucionalistas, deve, em seu âmago, gerar a consolidação do Estado Democrático de Direito concretizando e garantindo direitos. Para tal, o conteúdo da decisão nestes novos tempos não pode simplesmente se preocupar em encerrar conflitos, mas, sobremodo, deve iniciar a construção de um novo habitat social.

A prática decisória nesse novo sentido emprestado ao "decidir em processo" - decidir no ambiente processual - deve ter presente, para além de decidir o conflito, gerar uma resposta constitucionalmente adequada ao caso concreto. Ou seja, em meio ao novo paradigma, é necessário responder ao caso concreto norteado pela Constituição. O caminho a ser trilhado até a obtenção da decisão jurídica não mais se faz paralelo ao texto constitucional, mas sim entrecruzando-o.

A decisão, assim, passa a ser sempre constitucional por estar assentada sobre os ditames da Lei Maior, seja no momento em que os direitos ali albergados são violados, ou quando estes mesmos direitos sequer encontram-se materializados no corpo da sociedade. Para isso, torna-se imprescindível que a decisão nesta quadra da história dê-se jogada no mundo, ou seja, que assim como o ser, seja ela também um existencial hermenêutico, que ela mesma tenha desvelado o seu "ser" - ser de um ente..$^{34}$

Nessa maré, vislumbra-se a roupagem eminentemente hermenêutica do Direito Processual. Processo se faz no mundo, no tempo, buscando sentidos através da compreensão hermenêutica - circular hermenêutica - dos fatos

\footnotetext{
${ }^{32}$ SALDANHA, Jânia Maria Lopes. A Paradoxal Face Hipermoderna do Processo Constitucional: um olhar sobre o direito processual brasileiro. Estudios Constitucionales. Chile, $\mathrm{n}^{\circ} 2,2010$, p. 675-707.

33 SALDANHA, Jânia Maria Lopes Saldanha. A Jurisdição Partida ao Meio: a (in)visível tensão entre eficiência e efetividade. In: STRECK, Lenio Luiz; BOLZAN DE MORAIS, José Luis (Org). Constituição, Sistemas Sociais e Hermenêutica: anuário do programa de pós-graduação em Direito da UNISINOS - $\mathrm{n}^{\circ}$ 6. Porto Alegre: Livraria do Advogado, 2010, p. 79.

${ }^{34}$ OLIVEIRA, Rafael Tomaz de. Decisão Judicial e o Conceito de Princípio: A hermenêutica e a (in)determinação do Direito. Porto Alegre: Livraria do Advogado, 2008. Passim.
} 
trazidos ao mundo processual, que, embora seja dimensão diversa, por óbvio se perfaz em determinado momento histórico-temporal ${ }^{35}$.

Nestes novos tempos, passa - ou deve passar - a relação jurídicoprocessual a ser, além dela mesma, uma relação hermenêutico-processual de desvelamento do significado constitucional dos fatos - do ser constitucional do próprio processo - no momento da decisão jurídica - de obtenção da resposta correta ${ }^{36}$; resposta que deve nascer com a marca de um Direito construído sobre padrões de integridade e coerência jurídico-político-social. A resposta correta "surge", assim, de um ambiente processual democráticoconstitucionalizado que pauta a busca por ela - resposta - em uma conduta íntegra e coerente com o Direito institucionalizado - socialmente.

Neste meio de integridade e coerência, surge uma resposta corretamente baseada em todo um agir ético-moral da comunidade. Socialmente, devem os sujeitos de direito guiarem-se por esses padrões de integridade; politicamente, devem, estes mesmos sujeitos e, ademais, o legislador guiarem-se na conformação de suas práticas para com esse âmbito maior; e juridicamente, trilhará o intérprete o caminho do processo buscando incessantemente tais padrões jurídico-valorativos no acontecer da resposta devida ao caso concreto. ${ }^{37}$

O direito como integridade pede que os juízes admitam na medida do possível, que o direito é estruturado por um conjunto coerente de princípios sobre a justiça, equidade e o devido processo legal adjetivo, e pede-Ihes que os apliquem nos novos casos que se Ihes apresentem, de tal modo que a situação de cada pessoa seja justa e eqüitativa segundo as mesmas normas. ${ }^{38}$

Assim, dworkinianamente, porque não vislumbrar o processo - processo civil - como uma comum-unidade hermenêutico-integrativa que possibilita abandonar-se a ilusória busca pela verdade - por uma mera decisão resolutória - entico-objetificada e, adentrar-se o signo do novo paradigma da busca pelas respostas constitucionalmente adequadas aos casos concretos ${ }^{39}$ ? Quer dizer, vislumbrar esta comum-unidade processual - jurisdicional - como um horizonte de compreensão de sentido - do sentido constitucional dos fatos -,

\footnotetext{
${ }^{35}$ SALDANHA, Jânia Maria Lopes. A Paradoxal Face Hipermoderna do Processo Constitucional: um olhar sobre o direito processual brasileiro. Estudios Constitucionales. Chile, $\mathrm{n}^{\circ} 2,2010$, p. 675-707.

${ }^{36}$ STRECK, Lenio Luiz. Verdade e Consenso: constituição, hermenêutica e teorias discursivas. Rio de Janeiro: Lumen Juris, 2006. Passim.

${ }_{37}$ DWORKIN, Ronald. O Império do Direito. Tradução: Jefferson Luiz Camargo. São Paulo: Martins Fontes, 2007, p. 272-274.

${ }^{38}$ DWORKIN, Ronald. O Império do Direito. Tradução: Jefferson Luiz Camargo. São Paulo: Martins Fontes, 2007, p. 291.

${ }^{39}$ OLIVEIRA, Rafael Tomaz de. Decisão Judicial e o Conceito de Princípio: A hermenêutica e a (in)determinação do Direito. Porto Alegre: Livraria do Advogado, 2008, p. 232.
} 
como uma possibilidade de estar jogado no horizonte hermenêutico, buscando uma resposta constitucionalmente histórica - parte de uma história - que se materializara no momento da decisão ${ }^{40}$.

$\mathrm{E}$, essa nova jurisdição, enquanto comum-unidade hermenêutico-integrativa, será - é - a responsável por pensar o direito como condição de possibilidade para garantir e efetivar os direitos sociais. É o meio apto a levar ao direito as complexidades sociais do nosso tempo. Ou seja: a jurisdição de um Estado Democrático de Direito acontece efetivamente quando os direitos e garantias fundamentais acontecem no desvelamento de seu ser - ser de um ente -, perfectibilizados na decisão jurídica. ${ }^{41}$

Desse modo, a decisão que se requer face ao Estado Democrático de Direito é a decisão que, inserida nesse novo contexto político-jurídicosocial, preocupe-se com o mesmo - contexto -, pautando-se na consolidação deste Estado Democrático de Direito e na garantia da substancialidade constitucional que trouxe á reboque o novo paradigma. Decidir será garantir e concretizar direitos, será tanto reparar quanto impedir que direitos sejam lesionados, será perfectibilizar o direito no caso posto, assegurando a concretude da Constituição a partir do fato submetido a juízo. ${ }^{42}$

O direito só se materializará enquanto direito nesta nova roupagem paradigmática por meio do caso concreto que exige mais que apenas a resolução conflitiva, que exige uma resposta constitucionalmente apta a resolvê-lo ${ }^{43}$. Por isso que, ao agir processualmente, o juiz deverá pautar-se na integridade, na coerência, na tradição, nas respostas que integrativamente foram construídas anteriormente. Agir em jurisdição nesta época é uma questão de história efeitual, é seguir hermeneuticamente o caminho processual jurisdicional - na busca pela resposta constitucionalmente adequada ao caso concreto, que desvelada será no momento decisório. ${ }^{44}$

Nesse trilhar, o que deve estar claro é que se exige uma nova jurisdição que não se volte apenas aos direitos individuais, figuras centrais do liberalismo, mas sim que esteja adstrita aos desideratos do Estado Democrático de Direito. Uma jurisdição que caminhe ao encontro do direito constitucionalmente considerado e que atenda á materialidade jurídica, tendo o processo como um caminho apto à realização do direito material.

\footnotetext{
${ }^{40}$ RAMIRES, Maurício. Crítica à Aplicação de Precedentes no Direito Brasileiro. Porto Alegre: Livraria do Advogado, 2010, p. 96-97.

${ }^{41}$ HOMMERDING, Adalberto Narciso. Fundamentos para uma Compreensão Hermenêutica do Processo Civil. Porto Alegre: Livraria do Advogado, 2007, p. 174.

${ }^{42}$ SALDANHA, Jânia Maria Lopes. A Paradoxal Face Hipermoderna do Processo Constitucional: um olhar sobre o direito processual brasileiro. Estudios Constitucionales. Chile, $\mathrm{n}^{\circ}$ 2, 2010, p. 675-707.

${ }^{43}$ HOMMERDING, Adalberto Narciso. Fundamentos para uma Compreensão Hermenêutica do Processo Civil. Porto Alegre: Livraria do Advogado, 2007, p. 268-269.

${ }^{44}$ RAMIRES, Maurício. Crítica à Aplicação de Precedentes no Direito Brasileiro. Porto Alegre: Livraria do Advogado, 2010, p. 98-99.
} 
Dessa forma, a roupagem da decisão jurídica também será outra que não a meramente resolutória de um conflito individual de direitos. A decisão jurídica nesta quadra da história será a que na busca da resposta correta garanta e concretize os direitos postos constitucionalmente. Será uma decisão com valor hermenêutico, pautada pela integridade e coerência no direito, realizadorado direito material.

\section{CONSIDERAÇÕES FINAIS}

A modernidade relegou-nos um sistema jurídico fechado em si próprio, ensimesmado para com as coisas do mundo. Em que somente era Direito o que estava dado a priori pela codificação, pelo Estado, pelo soberano, não havendo espaço para os acontecimentos ocorridos fora do plano jurídico. Também nos deixou como herança uma racionalidade técnico-burocrática no concernente ao manejo do Direito. Tal racionalidade jurídica é o que serve de sustentáculo para um modelo processual forjado a partir das revoluções burguesas, o qual tinha por objetivo primeiro sustentar um ambiente de mobilidade social e a consequente ascendência da burguesia ao poder.

Este sistema processual oferece ao povo um modelo de tutela jurisdicional que somente tinha função e capacidade para garantir o funcionamento da máquina estatal liberal num regime de não intervenção da esfera privada. Para a jurisdição liberal, bastava garantir aos particulares um espaço para livre contratar, bem como, garantir o contrato e proteger os sujeitos jurídicosociais contra possíveis excessos do Estado. Logo, tal jurisdição é construída para atender a uma conflituosidade de cunho individual, ressarcitório e reparatório. Os direitos envolvidos em disputa são direitos meramente do indivíduo, em conflito com outro indivíduo ou com o ente estatal. Assim, este modelo de jurisdição contenta-se com a mera resolução do conflito, cabendo ao juiz mecanicamente determinar o quantum indenizatório devido pela violação de um direito - individual (Parte1).

Porém, tal situação modifica-se com a passagem ao Estado Social de Direito, fazendo exsurgir um processo também social(izado), que passa a ser responsável pela instituição da questão social no âmbito político-jurídico. O modelo estatal social faz com que a máquina estatal, para além da não intervenção, passe a conduzir o modo de agir político-jurídico para uma compreensão social do Direito, fazendo com que se forje uma esfera de proteção ampliada e que não se basta com o simples proteger, mas, sim, com o agir em busca do social. Tal modificação acentua-se ao se adentrar o paradigma do Estado Democrático de Direito que, como dito anteriormente, acontece como um plus normativo aos modelos anteriores e carrega consigo um caráter modificador do status quo, porque trazem, em sua conteudística, os direitos humano-fundamentais-sociais agora positivados e garantidos constitucionalmente.

Este corte paradigmático gera o surgimento de uma nova conflituosidade mais complexa, porque atinente a novos direitos não positivados anteriormente. 
Provoca, também, um aumento da litigiosidade, porquanto, aos sujeitos jurídico-sociais agora são alcançados direitos que devem ser garantidos e concretizados e que, em não sendo, deve o judiciário - via jurisdição propiciar o acontecer destes novos direitos (Parte 2).

Assim, exige-se um novo processo, bem como, uma nova jurisdição, capaz de atender às complexidades da sociedade contemporânea. Esta nova jurisdição deve nascer marcada pela hermenêutica e, por um modo de agir em processo, integrativo e coerente com a prática político-jurídica-social, que possibilite para além da mera resolução do conflito, o encontro do intérprete com a resposta constitucionalmente adequada ao caso concreto, consubstanciada na concretização e garantia de direitos.

\section{REFERÊNCIAS}

BARZOTTO, Luis Fernando. O Positivismo Jurídico Contemporâneo: uma introdução a Kelsen, Ross e Hart. Porto Alegre: Livraria do Advogado, 2007.

BOLZAN DE MORAIS, José Luis; STRECK, Lenio Luiz. Ciência Política e Teoria do Estado. Porto Alegre: Livraria do Advogado, 2010.

BOLZAN DE MORAIS, José Luis; SALDANHA, Jânia Maria Lopes; ESPÍNDOLA, Ângela Araújo da Silveira. Jurisdição Constitucional e Participação Cidadã: por um processo formal e substancialmente vinculado aos princípios político-constitucionais. In: OLIVEIRA, Marcelo Andrade Cattoni de; MACHADO, Felipe Daniel Amorim. (Org). Constituição e Processo: A colaboração do processo ao constitucionalismo democrático brasileiro. Belo Horizonte: Del Rey, 2009.

CAPPELLETTI, Mauro. Juízes Legisladores?. Tradução: Carlos Alberto Alvaro de Oliveira. Porto Alegre: Sergio Antonio Fabris, 1993.

CHEVALLIER, Jacques. O Estado Pós-Moderno. Tradução: Marçal Justen Filho. Belo Horizonte: Fórum, 2009.

DAMASKA, Mirjan. R. Las Caras de la Justicia y el Poder del Estado: análisis comparado del processo legal. Tradução: Andrea Morales Vidal. Santiago: Editorial Jurídica de Chile, 2000.

DWORKIN, Ronald. O Império do Direito. Tradução: Jefferson Luiz Camargo. São Paulo: Martins Fontes, 2007.

HOMMERDING, Adalberto Narciso. Fundamentos para uma Compreensão Hermenêutica do Processo Civil. Porto Alegre: Livraria do Advogado, 2007.

ISAIA, Cristiano Becker. Processo Civil, Atuação Judicial e Hermenêutica Filosófica: a metáfora do juiz instrutor e a busca por respostas corretas em direito. Faticidade e Oralidade. Curitiba: Juruá, 2010.

KELSEN, Hans. Teoria Pura do Direito. Tradução: João Baptista Machado. São Paulo: Martins Fontes, 2006.

LIPOVETSKY, Gilles; CHARLES, Sebastien. Os Tempos Hipermodernos. Tradução: Mário Vilela. São Paulo: Barcarolla, 2004.

LYOTARD, Jean-François. A Condição Pós-Moderna. Tradução: Ricardo Corrêa Barbosa. Rio de Janeiro: José Olympio, 2011. 
LUCAS, Doglas César. A Crise Funcional do Estado e o Cenário da Jurisdição Desafiada. In: BOLZAN DE MORAIS, José Luis (Org). O Estado e Suas Crises. Porto Alegre: Livraria do Advogado, 2005.

NUNES, Dierle José Coelho Nunes. Apontamentos Iniciais de um Processualismo Constitucional Democrático. In: OLIVEIRA, Marcelo Andrade Cattoni de; MACHADO, Felipe Daniel Amorim (Org). Constituição e Processo: a contribuição do processo ao constitucionalismo democrático brasileiro, Belo Horizonte: Del Rey, 2009.

OLIVEIRA, Rafael Tomaz de. Decisão Judicial e o Conceito de Princípio: a hermenêutica e a (in)determinação do Direito. Porto Alegre: Livraria do Advogado, 2008.

RAMIRES, Maurício. Crítica À Aplicação de Precedentes no Direito Brasileiro. Porto Alegre: Livraria do Advogado, 2010.

SALDANHA, Jânia Maria Lopes Saldanha. A Jurisdição Partida ao Meio: a (in)visível tensão entre eficiência e efetividade. In: STRECK, Lenio Luiz; MORAIS, José Luis Bolzan de (Org). Constituição, Sistemas Sociais e Hermenêutica: anuário do programa de pós-graduação em Direito da UNISINOS - $n^{0}$ 6. Porto Alegre: Livraria do Advogado, 2010.

SALDANHA, Jânia Maria Lopes. A Paradoxal Face Hipermoderna do Processo Constitucional: um olhar sobre o direito processual brasileiro. Estudios Constitucionales. Chile, $\mathrm{n}^{\circ} 2,2010$.

SILVA, Ovídio A. Baptista da. Processo e Ideologia: o paradigma racionalista. Rio de Janeiro: Forense, 2006.

SPENGLER, Fabiana Marion. A Crise da Jurisdição e a Necessidade de Superação da Cultura Jurídica Atual: uma análise necessária. In: BRANDÃO, Paulo de Tarso; SPENGLER, Fabiana Marion (Org). Os (Des)Caminhos da Jurisdição. Florianópolis: Conceito, 2009.

STRECK, Lenio Luiz. Verdade e Consenso: constituição, hermenêutica e teorias discursivas. Rio de Janeiro: Lumen Juris, 2006.

STRECK, Lenio Luiz. Hermenêutica Jurídica e $(m)$ Crise: uma exploração hermenêutica da construção do Direito. Porto Alegre: Livraria do Advogado, 2005.

STRECK, Lenio Luiz. O Que é Isto - decido conforme minha consciência?. Porto Alegre: Livraria do Advogado, 2010.

WARAT, Luis Alberto. Introdução Geral ao Direito II: a epistemologia jurídica da modernidade. Porto Alegre: Sergio Antonio Fabris, 1995. 